\title{
The Tragedy of Ukraine
}

\section{Hard Lessons to Learn from Classics}

Nicolai N. Petro

\begin{abstract}
"Tragedy rests not in the individual destiny... but in the general condition, of a people reducing or destroying itself because it is not conscious of its true condition"
\end{abstract}

Raymond Williams, Modern Tragedy

\section{Abstract}

As the war in Ukraine enters its fifth year, it remains mired in debt, corruption, and strife. The country seems to be caught up, again, in a vicious cycle that has been repeating itself for decades, if not centuries. Classical Greek tragedy gives us a deeper look at the reasons behind Ukraine's persistent failure to achieve social stability, and to suggest remedies. The tragic cycle can be broken through a compromise in which individual, social and divine aspirations for justice are reconciled. As long as Ukrainian leaders seek to achieve justice without compromise, the nation's self-destructive cycle is likely to persist.

Keywords: Ukraine, Russian-Ukrainian relations, Maidan, Greek tragedy, Donbass, Russophone Ukrainians.

\footnotetext{
Nicolai N. Petro University of Rhode Island (USA).

ORCID: 0000-0001-9834-1708

Department of Political Science

University of Rhode Island

Kingston, RI 02881 (USA)

Tel: +1 (401) 424-1812

e-mail: npetro@uri.edu

web site: www.npetro.net
}

Silvia-Chandley Professor of Peace Studies and Nonviolence and Professor of Political Science,

DOI: $10.31278 / 1810-6374-2018-16-4-52-71$ 


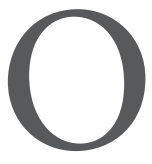

ne's view of the crisis in Ukraine depends on one's view of the nature of the conflict. Some see it as a civil war; others see it as Russian aggression. Many Ukrainians see elements of both (Detector.media, 2018; GfK Ukraine, 2017). I regard it as a conflict with deep domestic roots in which many external parties are also involved. All of these actors, foreign and domestic, are pursuing their own interests. As civil conflicts go, this one is rather typical. From the outset, it has been marked by a high degree of hostility, directed outward at "the aggressor nation," as well as inward at "the fifth column" that ostensibly supports it (Zerkalo nedeli, 2018; Fakty.ua, 2018; Gordonua.com, 2017). This has created a siege mentality within the Ukrainian elite that has stymied progress in resolving the conflict.

To understand how this situation came about and what can be done about it, it is helpful to view the Ukrainian crisis through the lens of what Richard Ned Lebow (2003) calls "the tragic vision of politics," a view that is rooted in classical Greek tragedy. Lebow focuses particular attention on the lessons that Thucydides imparts in his study of another fratricidal conflict-the Peloponnesian War. These can be summarized as follows: in the headstrong pursuit of their interests, key actors discarded the conventions (nomos) that once sustained the political community. As a result, the dialogue necessary for the survival of community (homonoia) became impossible. This led to the culminating tragedy—nemesis—or "the wrath of the gods."

I shall return to the implications of this tragic vision of politics for Ukraine later. First, however, it is important to understand the deepseated social anxieties that led to the present conflict, why the Second Minsk Accords have failed, and why outside intervention is unlikely to improve matters until a fundamental effort at reconciliation takes place within Ukrainian society.

\section{UKRAINE: A CLEFT COUNTRY}

More than twenty years ago, Samuel P. Huntington (2007: 138) described Ukraine as a country "cleft" between its Ukrainian-speaking West and its Russian-speaking East. Within Ukraine he even singled out Crimea as a region of particular contention. After Ukraine's independence 
this cleavage between the two main patterns of Ukrainian political, cultural, linguistic, and religious identity was successfully managed by alternating political power between East and West. The resulting political gridlock served to prevent civil war, which many observers believed would erupt if either side gained total political control and turned its version of Ukrainian identity into a test of civic loyalty.

President Yanukovich's removal from power on February 22, 2014 upset this delicate political balance and was immediately perceived as a direct threat by Russophone Ukrainians. Two-thirds of Donbass residents surveyed in April 2014, soon after the Maidan, said they regarded it as "an armed overthrow of the government, organized by the opposition with the assistance of the West" (Zerkalo nedeli, 2014). As Figure 1 shows, two-and-a half years later many Ukrainians, especially in the East and South, still think so.

Figure 1. "Kiev events of the winter of 2014 are an illegal military coup d'etat"

\begin{tabular}{|l|c|c|c|}
\hline Region & Agree, \% & Don't Agree, \% & Don't Know, \% \\
\hline West & 20.6 & 69.1 & 10.3 \\
\hline Center & 24.3 & 53.4 & 22.2 \\
\hline South & 51.1 & 33 & 15.9 \\
\hline East & 57.3 & 21.1 & 21.5 \\
\hline All Ukraine & 34.3 & 48.3 & 17.3 \\
\hline
\end{tabular}

Source: Media sapiens, 2017: 8-1

\section{THE MINSK ACCORDS: AN UNWANTED MECHANISM FOR RESOLVING CIVIL CONFLICT}

Both Russia and the West say they want a politically and socially stable Ukraine, but they disagree about how that stability can be achieved. Most Western decision-makers assume that if corruption is reduced, the economy will grow. Out of this growth a new political consensus will develop and cultural divisions will eventually become a thing of the past.

Most Russian decision-makers, on the other hand, views Ukraine as a culturally fragmented society. Stability, they say, can be achieved 
only if political authorities in Kiev acknowledge the bi-cultural nature of Ukraine and create a constitutional framework that grants the country's major cultural constituencies equal rights. Both sides do, however, agree on one thing, at least for now-that the mechanisms for re-integrating Donbass and forging long-term stability in Ukraine are spelled out in the Second Minsk Accords (OSCE, 2015).

The first three points of these Accords deal with the separation of forces; the remaining ten points are all political confidence-building measures. Point 5 calls for the pardon and amnesty of those engaged in the conflict. Ukraine's parliament, the Verkhovna Rada, did pass such an amnesty law, but in its current form it only applies to Ukrainian soldiers and volunteers.

Points 7 and 8 call for restoring economic and financial ties with Kiev. Instead, the Verkhovna Rada has instituted checkpoints, shut down banking and social services, suspended the local payment of pensions, and restricted railroad transportation, cell phone service, water and electricity supplies to the rebel-held regions.

Point 9 stipulates that control of the border will be transferred to Kiev after local elections and a comprehensive political settlement to be achieved by the end of 2015. A comprehensive political settlement is defined in point 11 as the adoption of constitutional amendments on decentralization that include a local police force, and the right to use the local language.

In sum, the Second Minsk Accords treat the crisis as a civil conflict and commits both Kiev and the rebels to a process of reconciliation through direct negotiations aimed at institutionalizing cultural pluralism in Ukraine. However, since the current government in Kiev is committed to the total Ukrainianization (Ritm Eurasii, 2017a), it has permanently set aside discussion of the constitutional changes required by Minsk.

Under pressure from Germany and France, a temporary extension of the Minsk Accords (Law 7164) was passed in October 2017 and renewed again a year later (Verkhova Rada Ukraini, 2017). To gain support in parliament for the first extension, a law on measures to restore state sovereignty (Law 7163) was introduced simultaneously. It lays out a Ukrainian strategy for regaining control of its lost territories that is sub- 
stantially different from the Minsk Accords. Under this new law Ukrainian military actions in Eastern Ukraine are no longer considered an antiterrorist operation but are now a "military operation with the aim of counteracting Russian aggression" (Golos Ukrainy, 2018). A Unified Forces commander appointed by the president will supervise local government, trade and commerce, as well as military activities in the region.

The law also shifts future reconstruction costs for the war-torn regions from Ukraine to Russia. Under the previous "anti-terrorist" designation, compensation for a person's material losses was the responsibility of the government, as stipulated in Article 19 of Ukraine's Law "On the Struggle Against Terrorism" (Verkhovna Rada Ukraini, 2003). Now that the military operation has been officially designated a struggle against external aggression, however, compensation can only be sought from Russia and to encourage suits against Russia, Ukrainians have been freed from having to pay the customary court fees (Romanov, 2018).

Figure 2. "The Kiev government is intentionally breaking a truce and the Minsk process."

\begin{tabular}{|l|c|c|c|}
\hline Region & Agree, \% & Don't Agree, \% & Don't Know, \% \\
\hline West & 26.8 & 58 & 15.1 \\
\hline Center & 37.5 & 40.4 & 25 \\
\hline South & 54.5 & 25.4 & 20.1 \\
\hline East & 45,0 & 26.8 & 28.4 \\
\hline All Ukraine & 38.8 & 39.6 & 21.5 \\
\hline
\end{tabular}

Source: Media sapiens, 2017: 8-6

The reaction of EU governments to Law 7163 has been limited to disappointment that it does not specifically mention the Second Minsk Accords. This is not a coincidence. Kiev's new interpretation of the Accords, which places control of the border before local elections, rather than after them as stipulated in Point 9, is now the law. As a result, not only is there no roadmap to reintegration, but no roadmap that is based on the Second Minsk Accords is now legally possible. While Kiev still insists that it continues to abide by the Accords, Figure 2 suggests that many Ukrainians are less convinced. 


\section{THE VIEW FROM INSIDE UKRAINE}

Within Ukraine today, there are at least three distinct approaches to how to resolve this conflict. The nominal political opposition (Oppobloc, $\mathrm{Za}$ Zhittya, Nashi), which is popular in the East and South, takes the view that the conflict will continue as long as the government regards a third of the country as a potential "fifth column" (Lenta.ru, 2018). They argue that the rebel cause, whether justified or not, has significant local support. The only solution, therefore, is to begin direct negotiation with the rebels so that the Second Minsk Accords can be implemented.

Ukrainian nationalists and the "Party of War" (a group that includes the heads of security and military affairs, the speaker of parliament, the former prime minister, and the Donbass governors appointed by Kiev) routinely disparage Eastern Ukrainians as disloyal (Zerkalo nedeli, 2015; Ukraina.ru, 2016; Tovt, 2016; Ukrainska pravda, 2015). They insist that Ukraine is at war with Russia and that the only solution is a decisive military victory, that some hope will also topple the regime in Moscow (Zerkalo nedeli, 2016; Ukrainska pravda, 2016b). According to Alexander Turchinov, the head of the National Security and Defense Council, Law 7163 "does not exclude such a path and creates preconditions for it” (Gordonua.com, 2018).

President Poroshenko and his allies constitute the third group. They, too, argue that the conflict was instigated by Russia and see it as a war, but they do not believe a military solution is possible. They propose increasing Western pressure on Russia until it is forced to return Donbass and Crimea to Ukraine.

Today, the opposition, though it still dominates local politics in the eight predominantly Russian-speaking regions of Ukraine, has almost no influence on national policy. The Party of War claims to have the support of several Cabinet members, the National Guard, and the Ministry of Internal Affairs. This leaves President Poroshenko caught in the middle. He cannot openly oppose the nationalists, for fear of violence. At the same time, he cannot openly abandon the Minsk Accords, for fear of losing Western support. The result is the paralysis that we have been witnessing over the past five years. The legislation passed in 2017 and 2018 has solidified this paralysis into a permanently fro- 
zen conflict, which suits the government and the Party of War just fine because it prevents some five million potential opposition voters in these regions (Strana.ua, 2018), and another 3-3.5 million Ukrainians living in Russia (Ukrinform.ru, 2018), from participating in the 2019 presidential and parliamentary elections. This amounts to more than $20 \%$ of potential voters (Derzhavnyi reester vybortsiv, 2018).

\section{MORE CRISIS LOOMS IN 2019}

As we approach these elections, the crisis within Ukraine will almost certainly deepen, since the government's policies undermine stability in three important ways.

First, while the Ukrainian economy desperately needs investment, the government is doing everything that it possibly can to prevent its main historical investor-Russia-from putting any money into Ukraine. Meanwhile, no one else is in any rush to do so. Ukraine's reformers had hoped to use IMF pledges, along with the temporary export preferences obtained through the EU Partnership Agreement, to attract foreign investment. Alas, the $\$ 2.3$ billion in total foreign direct investment that Ukraine attracted in $2017,60 \%$ of which goes to the city of Kiev, vanishes into insignificance compared to the $\$ 100$ billion it has lost in trade with Russia since 2012 (Ekonomicheskaia pravda, 2018; Seleznyov, 2016).

At the same time, in what can only be termed a form of fiscal waterboarding, over the next five years Ukraine must repay $\$ 28.7$ billion to foreign debt holders (Ritm Eurasia, 2017). In 2019, a peak year for repayments, nearly one-third of Ukraine's budget will have to be handed over to the IMF. We are already seeing a critical shortage of both cash and investment, requiring even more IMF funds, just to cover current government expenses. In August 2018, for the first time in the history of independent Ukraine, pension payments were delayed for two weeks, because there was simply not enough money on hand to pay them.

Second, at a time when the government should be trying to reduce domestic tensions, it is actually increasing social friction by imposing unpopular local name changes, promoting controversial Western Ukrainian historical figures, suppressing the use of the Russian language (Colás, 2018), and trying to replace the canonical Ukrainian Orthodox 
Church with a new church that is more politically loyal (Petro, 2018). According to one national poll, commissioned in early 2018, 61\% of Ukrainians were opposed to further de-communization and wanted to see former place names restored (Medvedchuk, 2018). In the Eastern and Southern regions of Ukraine similar surveys typically yield results of 75-80\% (Stremidlovsky, 2016; Doroshenko, 2017; Strana.ua, 2017). But instead of responding to local complaints, the government has doubled the budget of the controversial Institute for National Memory, which is spearheading these initiatives (Timer, 2018).

Last year the government also blocked the country's most popular social media sites, because they were Russian, and temporarily banned all books from Russia that are not for personal use. The new book licensing procedure for Russian books has cut the number of books allowed into Ukraine by $90 \%$, resulting in a thriving black market (Shumilo, 2018). Despite the Ukrainian government's best efforts, however, Figure 3 suggests that these initiatives have not had much success in changing regional perceptions of Russia.

Figure 3. “Do you consider Russia an aggressor-nation with respect to Ukraine?" [selected regions-NNP]

\begin{tabular}{|l|c|c|}
\hline Region & Yes, $\%$ & No or Hard to Say, \% \\
\hline West & 82 & 19 \\
\hline Galicia & 94 & 6 \\
\hline East & 42 & 58 \\
\hline Donbass & 40 & 60 \\
\hline South & 33 & 67 \\
\hline All Ukraine & 63 & 37 \\
\hline
\end{tabular}

Source: Grigoryev, 2018

Finally, the crisis is likely to get worse because corruption has metastasized. A report in the Ukrainian newspaper Vesti (Petik and Ivanova, 2018) claimed that $\$ 1.3$ billion collected for the benefit of the Ukrainian military through a new tax on social services has simply vanished. No one is even sure if any of this money was ever used to 
support the military. The persistence of such incidents has led some analysts to conclude that the current conflict with Russia is simply too profitable for the current Ukrainian elites to give up. They point out that the first declarations of assets by public officials in 2016 revealed that Ukrainian members of parliament had amassed, on average, roughly $\$ 670,000$ in cash and $\$ 220,000$ in banks-about as much as the average U.S. member of Congress (Ukrainskii vybor, 2016). It is also telling that in 2017, while the number of millionaires (in hryvnia) fell by $24 \%$ nationwide, it actually doubled in the capital city of Kiev (Ukraina.ru, 2018).

As Figure 4 shows, while the regions of Ukraine may disagree about many things, the fact that the war has been a source of profit for the ruling class is something they all agree upon.

Figure 4. "The war goes on because it is profitable for the Ukrainian government and oligarchs."

\begin{tabular}{|l|c|c|c|}
\hline Region & Agree, \% & Don't Agree, \% & Don't Know, \% \\
\hline West & 66.7 & 15.1 & 18.1 \\
\hline Center & 60.6 & 17.1 & 22.3 \\
\hline South & 71.2 & 14.4 & 14.4 \\
\hline East & 64.8 & 16.7 & 18.5 \\
\hline All Ukraine & 65.5 & 15.8 & 18.7 \\
\hline
\end{tabular}

Source: Media sapiens, 2017: 8-7

With so much dysfunction within Ukraine, hopes for a resolution of the conflict have increasingly come to rest on the intervention of foreign actors. But the international community can do little to help so long as the three most important external parties-the EU, the U.S., and Russia-cannot agree on a common vision of Ukraine's future. In this context it is particularly important to emphasize that Ukraine cannot prosper without close ties with Russia. The reason should be obvious. No country in history has ever prospered by making itself the enemy of a wealthier and more powerful neighbor. 


\section{UKRAINE AS TRAGEDY}

We may now return to Greek tragedy and its value for understanding current events. As classically understood, a tragedy is not merely a sad situation or outcome. It is, rather, a set of consequences that unfold in response to the loss of order. The precise nature of the tragic disorder can vary, though it typically includes things like pride, lack of compassion, and arrogance. By exposing these flaws in both individuals and societies, tragedy moves us away from disorder to the restoration of order (Williams, 1966: 181; Lebow, 2001: 39).

The Peloponnesian War (431-404 BC) is the classic example (Lebow, 2003: 65-114). In Thucydides' telling, the Athenian leader Pericles is seduced by the prospect of a quick victory into making very socially divisive choices. He ignores custom (nomos) and justice (dike), which the gods gave to the people so that they could live in harmony with each other, and thereby "misses the mark" (hamartia) and elicits the wrath of the gods (nemesis). The once glorious Athenians are made to see their flaws through the resulting catastrophe (Lebow, 2003: 276).

There are at least three reasons to think of Ukraine's courageous revolutionaries, who seem determined to right the historical injustices that they believe were done to their ancestors, as tragic figures ensnared by the same trap, the arrogance commonly associated with greatness, which the Greeks called hybris. The result is an almost textbook example of peripeteia- "a reversal of fortune when a course of action designed for one result leads to its opposite" (Ferguson, 570).

The first reason is that, as their efforts met with increasing domestic resistance, rather than seeking reconciliation, it hardened their resolve to treat those who disagreed with them as enemies, even aliens. Thus, former Ukrainian President Viktor Yushchenko describes Crimea and Donbass as regions "where our language practically does not exist, where our memory is nonexistent, where our church is absent, where our culture is absent... utterly foreign lands [de chuzhina chuzhinoyu]" (Ukrainska pravda, 2014). One solution often proposed is to re-educate those populations into a proper appreciation of their Ukrainian identity, a process that Donetsk University professor Elena Styazhkina euphemistically terms "positive, peaceful colonization" (Fakty.ua, 2014). 
Thucydides would probably have described it as losing the ability to communicate with one's opponents (Lebow, 2003: 16).

A second reason is the intentional minimization of the cost of imposing Ukraine's new "civilizational choice." As they did in Athens, the choices made by the victors of the Maidan that alienated the populations of Donbass and Crimea had deeper structural causes. They flowed from the rejection of legal and governmental authority promoted by the leaders of the Maidan (Ukrainska pravda, 2018). With political discourse no longer rooted in shared ideals and identity, facts and social meanings quickly began to diverge, further encouraging one-sided policies. As Eastern and Western Ukraine settled into diametrically opposite interpretations of the 2014 Maidan (Petro, 2015: 29), all willingness to engage in dialogue evaporated, threatening the unity of the very state that all are ostensibly trying to save.

Finally, in a manner typical of so many classical Greek tragedies, the solution-strengthening the bonds of communal identity through dialogue and reconciliation-is as blindingly obvious as it is remote. The Greeks believed that true understanding (sophos skopein) derives from catharsis-sympathy for and co-suffering of another's pain. Justice demands that people treat each other as equals and see things from the other's point of view. Together, catharsis and justice help to forge the bonds of social affection that bring order to the polis. The sense of chaos and frustration that currently pervades Ukrainian society is therefore precisely what one would expect from the government's failure to cultivate the social affections of all Ukrainians (Grigoryev, 2018).

But classical Greek tragedy is not only analysis; it is also therapy. By reconciling with Ukraine's own Russophone citizens the cycle of hubris, hamartia, and nemesis could, potentially, be broken. Is it Ukraine alone that needs to take actions to reconcile with Russia? Not at all. This is a tragedy that involves both countries, precisely because they share a common heritage. For some Ukrainian intellectuals this common heritage is a blessing; for others it is a curse. As Ukrainian writer Yuri Andryukhovich has put it, "The conflict in Donbass is indeed a war of cultures. Theirs is called the 'Russian World; ours is called 'Free European Ukraine"' (Slavinska, 2015). The deeper tragedy, however, lies in the choice of the latter to use the Revolution of Dignity as a means to eradicate the former, 
rather than as a means to extend dignity to all. Figure 5 poignantly illustrates such an approach invariably imperils the unity of Ukraine.

Figure 5.

\begin{tabular}{|c|c|}
\hline $\begin{array}{c}\text { “Would you say that Russians } \\
\text { and Ukrainians are one } \\
\text { people?" }\end{array}$ & $\begin{array}{c}\text { “Would you say that Russians } \\
\text { and Ukrainians are brother } \\
\text { nations?" }\end{array}$ \\
\hline Yes $26 \%$ & Yes $51.1 \%$ \\
\hline No $65 \%$ & No $33.8 \%$ \\
\hline
\end{tabular}

Source: Ukrainska pravda, 2016; Forbes-Ukraina, 2016

This conflict is therefore not primarily about geopolitical advantagewhat the West stands to gain by separating Ukraine from Russia, or what Russia stands to gain by establishing its own strategic enclave in Crimea and Donbass. These alone would never cause Ukraine's president to rail so passionately against "the fifth column" within Ukraine. It is precisely the fact that one out of every three Ukrainians obstinately refuses to regard Russia as an "aggressor-nation" (Grigoryev, 2018) that reveals the full scope of the tragedy at the heart of this conflict, namely that opposing sides of the Ukrainian political community have adopted extreme positions about what constitutes justice.

The situation is not unlike the moral dilemmas that Sophocles portrays in his plays, Ajax and Antigone. Both revolve around the right of individuals to stand up against the authorities. In Ajax, the conflict between duty to the State and duty to the family is expressed in the family's desire to bury the dead, to whom authorities wish to deny this honor. It is resolved when Odysseus points out that there is a third and even higher obligation-loyalty to the sense of community. Once Ajax's mortal enemy in life, Odysseus demonstrates that loyalty by becoming Ajax's spokesman in death. By transcending his personal enmity, Odysseus demolishes any motive for future revenge by Ajax's family, and thus prevents the tragic cycle from being repeated by the next generation. In Antigone, by contrast, the tyrant Creon insists that Antigone's brother 
Polyneices may not be buried because "once an enemy, never a friend, not even after death!" (Meier, 1993: 190). Creon has Antigone walled up alive in a cave for defying his authority even though he understands perfectly well that his decree is unjust (even if Zeus' eagles were to swoop down and take Polyneices' up straight to Olympus, Creon says he would see no reason to bury the body). Creon believes that he is pursuing the polis' best interests. His absolute devotion to raison d'etat however prevents him from any dialogue, any compromise, any recognition of error. It is this that leads to his downfall. He does not understand that true justice requires the triumph of the whole, rather than the triumph of his own, partial justice. This is Antigone's failing too. She is so obsessed with her own partial justice that she will even commit a "holy" crime to achieve it.

What Sophocles seems to be suggesting is that conflicts over values and norms cannot be resolved by imposing the "better" value by force. The only real solution lies in reconciling the ideals of all, in recognizing the similarity of these ideals, and in being willing to sacrifice partial victory for the sake of those shared ideals. What classical Greek tragedy teaches us is that total victory, in any conflict, can only breed renewed conflict. Herein lies the crucial difference between an unfulfilled revolution that is destined to repeat itself, and a true revolution that has completed its full cycle. The latter regards the suffering of our opponents as our own suffering, rather than as a justification for more revolution, and more suffering.

It is therefore worth recalling that, back in May 2014, the Verkhovna Rada recognized the need to prioritize reconciliation, when it adopted a "Memorandum on Mutual Understanding and Peace" (Rada.gov.ua, 2014). It called upon all Ukrainians to "extend a hand to each other, to reject radical actions, hatred, and to restore, together, common efforts in defense, development, and the establishment of a democratic, sovereign and united Ukraine, in which people of all nationalities, political beliefs, and faiths can live in friendship." To accomplish this the Rada called for "a national dialogue within the framework of roundtable of national unity." Adopted just five days before the presidential elections, had this policy actually been implemented, Ukraine's subsequent history might have been very different. 
Still, tragedy also teaches us that there are no permanent solutions in human affairs, no permanently virtuous leaders, only lessons learned (or not learned) from the mistakes of the past. By reminding ourselves of these lessons, there is at least the hope that the cycle of enmity that led to a particular conflict can be broken. By emphasizing dialogue and reconciliation, tragedy is thus no more, and no less, than the foundation of peacemaking.

The path to peace, both inside Ukraine, and between Ukraine and Russia, is thus one and the same-dialogue and reconciliation. Indeed, for millions of people in Eastern and Southern Ukraine, reconciliation with Russia is clearly an essential component of their reconciliation with their fellow Ukrainians, since it would send an unmistakable signal that, regardless of their religion, language, and cultural heritage, they will be embraced as Ukrainians, and not treated as a fifth column within their own country. Ukraine's ability to break the cycle of tragedy ultimately depends on this.

\section{References}

Colás, X., 2018. Ucrania empieza a prohibir el ruso [Ukraine begins to prohibit Russian]. El Mundo, 14 October. Available at: http://www.elmundo.es/internacio nal/2018/10/14/5bc0e85522601df30c8b45c3.html [Accessed 1 December 2018].

Derzhavnyi reester vybortsiv, 2018. Vidomosti pro kilkist vybortsiv v mezhakh Avtonomnoi Respubliki Krym, oblastei, mist Kyiva ta Sevastopolya, zakordonnogo vyborchoho okruhu [Information on the number of voters within the Autonomous Republic of Crimea, oblasts, cities of Kyiv and Sevastopol, and foreign election districts] 31 December. Available at: https://www.drv.gov.ua/portal/

Detector.media, 2018. Doverie k SMI, vliyanie rossiiskoi propagandy, mediagramotnost $v$ Ukraine [Trust in mass media, the influence of Russian propaganda, and media competency in Ukraine]. Available at: http://detector.media/doc/ images/news/archive/2016/136017/AReport_Massmedia_Feb2018_v2.pdf [Accessed 1 December 2018].

Doroshenko, S., 2017. Eto kakoi-to pozor [This is something shameful]. PolitNavigator, 30 June. Available at: http://www.politnavigator.net/ehto-kakojj-topozor-moskal-pokhvalilsya-chto-pereimenoval-ulicu-v-mukachevo-v-chestnacista-shukhevicha.html [Accessed 1 December 2018]. 
Ekonomicheskaia pravda, 2018. Klichko: "60\% investitsii v Ukrainu prikhodiatsya na Kiev" [Klichko: "60\% of investments in Ukraine go to Kiev"]. 20 March. Available at: https://www.epravda.com.ua/rus/news/2018/03/20/635143/ [Accessed 1 December 2018].

Eurointegration.com, 2016. ES nashel vykhod is krizisa s Soglasheniem ob assotsiatsii s Ukrainoi [The EU has found a way out of the crisis involving the Association Agreement with Ukraine]. 16 December. Available at: https:// www.eurointegration.com.ua/rus/articles/2016/12/16/7058954/ [Accessed 1 December 2018].

Euromaidan Press, 2014. Ukrainian 'Banderite' nationalism: an inhumane ideology which has no place in XXI? 24 September. Available at: http://euromaidanpress.com/2014/09/24/ukrainian-banderite-nationalism-an-inhumane-ideology-which-has-no-place-in-xxi/ [Accessed 1 December 2018].

Fakty.ua, 2014. Professor DonNU Elena Styazhkina: "Donbas ne vernetsya $v$ Ukrainy potomu chto Donbas ne sushchestvuyet" [Professor of Donbass National University Elena Styazhkina: "Donbass will not return to Ukraine because Donbass does not exist"]. 6 November. Available at: http://fakty.ua/190599elena-styazhkina-Donbas-ne-vernetsya-v-ukrainu-potomu-chto-Donbasa-nesucshestvuet [Accessed 1 December 2018].

Fakty.ua, 2018. Na lbu ne napisano [It's not written on one's forehead]. 26 March. Available at: https://fakty.ictv.ua/ru/ukraine/20180326-na-lobi-ne-napysano-poroshenko-zayavyv-pro-p-yatu-kolonu-v-ukrayini/ [Accessed 1 December 2018]. Forbes-Ukraina, 2016. Bolee poloviny ukraintsev shchitayut rossiyan bratskim narodom [More than half of Ukrainians consider Russians to be a brother-nation]. 16 December. Available at: http://forbes.net.ua/news/1425670-bolee-polovinyukraincev-schitayut-rossiyan-bratskim-narodom [Accessed 1 December 2018].

GfK Ukraine, 2017. Ukrainske pokolinnia 'Z': tsinnosti ta orientiry [Ukraine's generation ' $Z$ ': values and orientations]. Available at: http://www.gfk.com/ fileadmin/user_upload/dyna_content/UA/02-News-2017/GfK-Ukr_Generation_ukr_inet-1.pdf [Accessed 1 December 2018].

Golos Ukrainy, 2018. Pro osoblivosti derzhanoi politiki iz zabepechnnya dezhavnogo suverenitetu Ukrainy na timchasovo okupovanykh teritoriyakh $u$ Donetskii ta Luhanskii oblastyakh [On the specifics of state policy on guaranteeing the sovereignty of Ukraine in the temporarily occupied territories of Donetsk and Luhanks regions]. 23 February. Available at: http://www.golos.com. ua/article/300158 [Accessed 1 December 2018]. 
Gordonua.com, 2017. Poroshenko: "Nam khvatit uma i sil, chtoby 'pyataya kolonna' i ne dumala podnyat golovu" [Poroshenko: "We have enough brains and strength to prevent the 'fifth column' from even thinking of raising its head"]. 24 August. Available at: http://gordonua.com/news/politics/poroshenkonam-hvatit-uma-i-sil-chtoby-pyataya-kolonna-i-ne-dumala-podnyat-golovu-203989.html [Accessed 1 December 2018].

Gordonua.com, 2018. Turchinov zayavil, chto zakon o reintegratsii Donbassa ne isklyuchaet osvobozhdenie okkupirovannykh territorii silovym putem [Turchinov says that the law on the reintegration of Donbass does not exclude the liberation of occupied territories by force]. 13 February. Available at: http:// gordonua.com/news/war/turchinov-zayavil-chto-zakon-o-reintegracii-donbassa-ne-isklyuchaet-osvobozhdeniya-okkupirovannyh-territoriy-silovymputem-231678.html [Accessed 1 December 2018].

Grigoryev, V., 2018. Voina i svoi put dlya Ukrainy - rezultaty sotsoprosa [War and Ukraine's distinct path - survey results]. KievVlast, 19 November. Available at: http://m.kievvlast.com.ua/text/vojna-i-svoj-put-dlya-ukrainyrezultatysotsoprosa [Accessed 1 December 2018].

Huntington, S., 2007. The Clash of civilizations and the remaking of world order. New York: Simon and Schuster.

Lebow, R., 2003. The Tragic vision of politics. Cambridge: Cambridge University Press.

Lenta.ru, 2018. Na Ukraine ispugalis za svoyu gosudarstvennost [In Ukraine, people fear for their statehood]. 12 August. Available at: https://lenta.ru/ news/2018/08/12/poteryaem/ [Accessed 1 December 2018].

Media sapiens, 2017. Survey of Russian propaganda influence on public opinion in Ukraine findings. 13 February. Available at: https://ms.detector.media/detector_media_en/reports_eng/survey_of_russian_propaganda_influence_on_ public_opinion_in_ukraine_findings/ [Accessed 1 December 2018].

Medvedchuk, V., 2018. Evroreformy po Groismanu [Euroreforms à la Hroysman]. Ukrainskii vybor, 30 January. Available at: http://vybor.ua/article/ sistemnye_problemy_gosudarstvennosti/evroreformy-po-groysmanu-vmestoevrostandartov-totalnaya-nishcheta.html [Accessed 1 December 2018].

Meier, C., 1993. The Political art of tragedy. Baltimore: Johns Hopkins University Press.

Milakovsky, B., 2018. Ukrainians abroad. Focus Ukraine, 7 February. Available at: http://www.kennan-focusukraine.org/ukrainians-abroad-the-economicsand-politics-of-labor-migration/ [Accessed 1 December 2018]. 
OSCE, 2015. Package of Measures for the Implementation of the Minsk Agreements. 12 February. Available at: https://www.osce.org/cio/140156 [Accessed 1 December 2018].

Petik, M. and Ivanova, E., 2018. Gde dengi? [Where's the money?]. Vesti, 29 January. Available at: https://vesti-ukr.com/strana/275230-kuda-ushelvoennyj-naloh [Accessed 1 December 2018].

Petro, N., 2015. Understanding the Other Ukraine: identity and allegiance in Russophobe Ukraine. In: Agnieszka Pikulicka-Wilczewska and Richard Sakwa, eds. Ukraine and Russia: people, politics, propaganda and perspectives. Bristol, UK: E-International Relations Edited Collections. Available at: http:// www.e-ir.info/2015/03/13/understanding-the-other-ukraine-identity-andallegiance-in-russophone-ukraine/ [Accessed 1 December 2018].

Petro, N., 2018. Russian-Ukrainian church turmoil driven by political ambitions. Russia Matters, 19 October. Available at: https://www.russiamatters.org/analysis/ russian-ukrainian-church-turmoil-driven-political-ambitions [Accessed 1 December 2018].

Poroshenko, P., 2018. Zvernenya Prezidenta Ukrainy do 27-i richnitsy referendum za Nezalezhnost Ukrainy [Address by the president of Ukraine on the 27th anniversary of the referendum on Ukraine's independence]. 1 December 2018. Available at: https://www.president.gov.ua/news/zvernennya-prezidentaukrayini-do-27-yi-richnici-referendumu-51598 [Accessed 1 December 2018]. Rada.gov.ua, 2014. Pro Memorandum porozuminnya i miru [About the Memorandum on Mutual Understanding and Peace]. 20 May. Available at: http://zakon.rada.gov.ua/laws/show/1280-18 [Accessed 1 December 2018].

Ritm Eurasii, 2017a. Poroshenko poobeshchal, chto na ukrainskom yazyke zagovorit vsya Ukraina [Poroshenko promises that all of Ukraine will speak Ukrainian]. 10 November. Available at: https://www.ritmeurasia.org/news2017-11-10-poroshenko-poobeschal-chto-na-ukrainskom-jazyke-zagovoritvsja-ukraina-33434 [Accessed 1 December 2018].

Ritm Eurasii, 2017b. Ukraina provozhaet 2017 god rastushchimi dolgami i inflyatsiei [Ukraine says good-bye to 2017 with increasing debt and inflation]. 29 December. Available at: https://www.ritmeurasia.org/news-2017-12-29ukraina-provozhaet-2017-god-rastuschimi-dolgami-i-infljaciej-34311 [Accessed 1 December 2018].

Romanov, A., 2018. Ni mira, ni voiny [Neither peace, nor war]. Strana.ua, 27 February. Available at: https://strana.ua/articles/rassledovania/126556novyj-zakon-ukrainy-o-reintehratsii-donbassa-fakticheski-otdaet-vlast-voennym.html [Accessed 1 December 2018] 
Seleznyov, M., 2016. Vozmushchenie ushcherba [Upset at loss] Lenta.ru, $18 \mathrm{Au}-$ gust. Available at: https://m.lenta.ru/articles/2016/08/18/ukrpain/ [Accessed 1 December 2018].

Shumilo, E., 2018. Te kto chitayut piratskoe, dolzhny za eto otvechat [Those who read contraband must answer for it]. Apostrophe.ua, 7 January. Available at: https://apostrophe.ua/article/society/culture/2018-01-07/te-kto-chitayutpiratskoe-doljnyi-za-eto-otvechat-izdatel-o-knigah-iz-rossii-i-kontrabandena-millionyi/16352 [Accessed 1 December 2018].

Slavinska, I., 2015. Yurii Andrukhovych: "Konflikt na Donbasi - tse naspravdi viyna kultur" [Yuri Andrukhovych: "The conflict in Donbass is indeed a war of cultures"]. Ukrainska pravda, 2 March. Available at: https://life.pravda.com.ua/ society/2015/03/2/190102/ [Accessed 1 December 2018].

Strana.ua, 2017. Podavlyaushchee bolshinstvo zhitelei Odessy - protiv snosa Ekateriny II. [The overwhelming majority of inhabitants of Odessa are against removing Catherine II monument]. 26 December. Available at: https://strana. ua/news/114035-novosti-odessy-odessity-protiv-snova-pamjatnika-ekaterineii.html [Accessed 1 December 2018].

Strana.ua, 2018. Peizazh pered bitvoi [The landscape before the battle]. 31 December 31. Available at: https://strana.ua/articles/analysis/178952-vybory31-dekabrja.html [Accessed 10 January 2019].

Stremidlovsky, S., 2016. Novyi raskol na Ukraine [A new divide in Ukraine]. IA Regnum, 15 December. Available at: https://regnum.ru/news/polit/2218086. html [Accessed 1 December 2018].

Timer, 2016. Turchinov vystupil za polnuyu izolyatsiyu Donbassa [Turchinov supports complete isolation of Donbass]. 26 December. Available at: http:// timer-odessa.net/news/turchinov_vistupil_za_polnuyu_izolyatsiyu_donbassa_383.html [Accessed 1 December 2018].

Timer, 2017. Zhiteli Yuga Ukrainy schitayut Evromaidan perevorotom. [The inhabitants of Southern Ukraine consider the Euromaidan a coup detat]. 14 February. Available at: http://timer-odessa.net/news/jiteli_yuga_ukraini_ schitayut_maydan_perevorotom_i_veryat_chto_voyna_na_donbasse_vigodna_kievu_849.html [Accessed 1 December 2018].

Timer, 2018. UPA - otvet nepokorennogo naroda [The UPA (Ukrainian Insurgent Army) is the response of a defiant people]. 23 October. Available at: http://timerodessa.net/news/upa_otvet_nepokorennogo_naroda_v_2019_godu_institutu_ natspamyati_udvoyat_finasirovanie_432.html [Accessed 1 December 2018]. Tovt, A., 2016. "Nichego ne znayu pro genetiku, ya Politekh zakanchival" ["I don’t 
know anything about genetics; I finished a polytechnic"]. Strana.ua, 30 November. Available at: http://strana.ua/articles/special/41886-nichego-ne-znayu-progenetiku-ya-politeh-zakanchival.html [Accessed 1 December 2018].

Ukraina.ru, 2016. Komandir Azova: "V Genshtabe byli gotovy sdat Khrakov" [The commander of the Azov battalion: "The General Staff was ready to surrender Kharkov"]. 20 December. Available at: https://ukraina.ru/ news/20161220/1018058867.html [Accessed 1 December 2018].

Ukraina.ru, 2018. Za god kolichestvo millionerov $v$ Kieve vyroslo $v d v o e$ [In one year the number of millionaires in Kiev has doubled]. 20 February. Available at: https:// ukraina.ru/news/20180220/1019964441.html [Accessed 1 December 2018].

Ukrainska pravda, 2014. Yushchenko pro Krym i Donbas: "Tam chuzhina chizhinoyu" [Yushchenko on Crimea and Donbass: "Those are utterly foreign lands"]. 26 December. Available at: http://www.pravda.com.ua/ news/2014/12/26/7053324/ [Accessed 1 December 2018].

Ukrainska pravda, 2015. Zhebrivsky prosit Poroshenko sozdat VGA vo vsekh raionakh Donetskoi oblasti [Zhebrivsky asks Poroshenko to set up VGAs (temporary government administrations) in all districts of the Donetsk region]. $13 \mathrm{Au}$ gust. Available at: https://www.pravda.com.ua/rus/news/2015/08/13/7077754/ [Accessed 1 December 2018].

Ukrainska pravda, 2016a. Polovina ukraintsev shchitayut rossiyan bratskim narodom [Half of Ukrainians consider Russians a brother-nation], 16 December. Available at: https://www.pravda.com.ua/rus/news/2016/12/16/7130036/ [Accessed 1 December 2018].

Ukrainska pravda, 2016b. Zhebrivsky govorit, chto khochet Bolshoi voinys Rossiei $z a$ Donbass [Zhebrivsky says he wants a Big War with Russia for Donbass]. 8 April. Available at: https://www.pravda.com.ua/rus/news/2016/04/8/7104896/ [Accessed 1 December 2018].

Ukrainska pravda, 2018. Parubii govorit, chto na Maidane byl zapasnoi "lvovskii" plan [Parubii says that at the Maidan there was a reserve Lvov plan]. 2 October. Available at: https://www.pravda.com.ua/rus/news/2018/10/2/7193828/. [Accessed 1 December 2018].

Ukrainskii vybor, 2016. V karmanakh deputatov oselo 2\% gosudarstvennogo budgeta na 2016 god [ $2 \%$ of the 2016 national budget fell into deputies' pockets]. 3 November. Available at: http://vybor.ua/news/smi_v_karmanah_deputatov_oselo_2_gosudarstvennogo_byu_1_eta_na_2016_god.html [Accessed 1 December 2018].

Ukrainskii vybor, 2018. Operatsiya 'Manipulyatsiya', ili kak sorovskii VoxCheck radi Medvedchuka na falsifikatsii poshel [Operation 'Manipulation', or how 
Soros' VoxCheck engaged in falsification because of Medvedchuk], 23 February. Available at: http://vybor.ua/article/zayavlenie/operaciya-manipulyaciyaili-kak-sorosovskiy-voxcheck-radi-medvedchuka-na-falsifikacii-poshel.html [Accessed 1 December 2018].

Ukrinform.ru, 2018. V Rossii zhivet pochti tri milliona Ukraintsev-Klimkin [Nearly three million Ukrainians live in Russia-Klimkin], 23 April. Available at: https://www.ukrinform.ru/rubric-society/2446887-v-rossii-zivet-pocti-trimilliona-ukraincev-klimkin.html [Accessed 10 January 2019].

Verkhovna Rada Ukraini, 2003. Pro borot'bu z terorizmom [On the struggle against terrorism]. Available at: http://zakon5.rada.gov.ua/laws/show/638-15 [Accessed 1 December 2018].

Verkhova Rada Ukraini, 2017. Proekt Zakonu pro stvorennyaneobkhidnykh umov dlya mirnogo vregulyuvannya situatsii $v$ okremykh raionakh Donetskoi ta Luhanskoi oblastei [Draft Law on the creation of the conditions necessary for the peaceful resolution of the situation in select districts of the Donetsk and Luhansk regions]. Available at: http://w1.c1.rada.gov.ua/pls/zweb2/ webproc4_1?pf3511=62641 [Accessed 1 December 2018].

Williams, R., 1966. Modern tragedy. Stanford, Calif.: Stanford University Press. Zerkalo nedeli, 2014. Mnenie i vzglyady zhitelei Yugo-Vostoka Ukrainy: Aprel' 2014 [The opinions of the inhabitants of Southwestern Ukraine: April 2014]. 18 April. Available at: http://zn.ua/article/print/UKRAINE/mneniya-i-vzglyady-zhiteleyyugo-vostoka-ukrainy-aprel-2014-143598_html [Accessed 1 December 2018].

Zerkalo nedeli, 2015. Zhebrivsky priglasil 500 patriotov na rabotu $v$ Donetskoi OGA [Zhebrivsky has invited 500 patriots to work in the Donetsk OGA (regional government administration)]. 7 July. Available at: https://zn.ua/UKRAINE/ zhebrivskiy-priglasil-500-patriotov-na-rabotu-v-doneckuyu-oga-181720_. html [Accessed 1 December 2018].

Zerkalo nedeli, 2016. Zhebrivsky sklonyaetsya $k$ khorvatskomu stsenariyu osvobozhdeniya Donbassa ot okkupantov [Zhebrivksy is leaning toward the Croatian scenario for liberating Donbass from its occupiers], 22 December. Available at: http://zn.ua/UKRAINE/zhebrivskiy-sklonyaetsya-k-horvatskomu-scenariyu-osvobozhdeniya-donbassa-ot-okkupantov-234052_.html [Accessed 1 December 2018].

Zerkalo nedeli, 2018. Poroshenko rasskazal o pyatoi kolonne $i$ atamanshchine [Poroshenko spoke of the fifth column and the Hetmanate]. 22 January. Available at: https://zn.ua/POLITICS/poroshenko-rasskazal-o-pyatoy-kolonne-iatamanschine-272799_.html [Accessed 1 December 2018]. 